\title{
In vitro Evaluation of Epiphytic Bacteria from Table Grapes for the Suppression of Botrytis cinerea
}

\author{
J.H.S. Ferreira
}

Viticultural and Oenological Research Institute (VORI), Private Bag X5026, 7600 Stellenbosch, Republic of South Africa.

Submitted for publication: February 1990

Accepted for publication: May 1990

Key words: Botrytis cinerea, biological control, table grapes.

\begin{abstract}
Epiphytic bacteria were isolated from leaves and bunches of Waltham Cross grapes and tested for their inhibition of Botrytis cineria. Trichoderma harzianum from grapevine wood was also evaluated. Eighty bacterial isolates inhibited germination of $B$. cinerea spores on potato dextrose agar. Sixteen of these isolates were tested in vitro for their efficacy against $B$. cinerea rot on grape berries (cv. Waltham Cross). One bacterial isolate totally inhibited $B$. cinerea whereas the efficacy of thirteen of the isolates, including $T$. harzianum, varied between 70,8 and $87,5 \%$. It was also demonstrated that certain fungicides exerted a negative effect on these bacterial isolates.
\end{abstract}

Botrytis cinerea Pers. Fr. is the major cause of the post-harvest decay of table grapes in South Africa (Thomas, 1983). Infection takes place in the vineyard and may remain latent in berries till after harvest. The control of $B$. cinerea on table grapes is based on regular chemical treatment, and owing to the very high cost of fungicides, the total expenditure in South Africa amounts to about R3 million per annum. Despite a chemical control programme the disease incidence may reach very high levels during some seasons and losses as high as R5 million may occur. Furthermore, the continuous use of these fungicides may result in the development of fungicide-resistant $B$. cinerea populations. In certain countries populations of $B$. cinerea resistant to dicarboximides (vinclozolin and iprodione), which are presently used in South Africa, already occur (Dennis \& Davis, 1979; Le Roux, Gredt \& Fritz, 1981; Katan, 1982).

For the same reason the use of benzimidazoles (e.g. benomyl) for the control of $B$. cinerea has been discontinued in a number of countries including South Africa.

Owing to the resistance factor and many other known detrimental effects of chemical control, there has been an increasing interest in the biological control of plant pathogens by means of non-pathogenic bacteria and fungi (Baker \& Cook, 1973). The biological control of B. cinerea has been obtained on a number of plant species with epiphytic bacteria or fungi (Wood, 1950; Tronsmo \& Dennis, 1977; Utkhede \& Sholberg, 1986; Redmond, Marois \& MacDonald, 1987; Nelson \& Powelson, 1988). For example, Dubos (1984) reduced bunch rot in grapes by using Trichoderma harzianum. Many Trichoderma isolates are antagonistic to a range of fungi (Dennis \& Webster, 1971a, 1971b).

Epiphytic bacteria, especially, have the potential to con- trol plant pathogens by means of their antagonistic influence (Leben, 1965; Blakeman \& Brodie, 1977; Fravel \& Spurr, 1977).

The present investigation was, therefore, undertaken to examine the potential of epiphytic bacteria, isolated from grapevine leaves and bunches, as biocontrol agents against $B$. cinerea on table grapes in the Western Cape.

\section{MATERIALS AND METHODS}

Sampling and isolation: Epiphytic bacteria were isolated at two-weekly intervals, from flowering until ripening, from leaves and bunches of a Waltham Cross vineyard at Paarl. The vineyard was divided into four blocks, each consisting of two rows of twelve vines each. Five bunches, picked at random per block, were macerated for 10 minutes in $100 \mathrm{ml}$ sterile distilled water in a Waring blender and filtered through cheesecloth. Dilutions of the filtrate $(1 \mathrm{ml}$ aliquots) were plated into molten nutrient agar (NA). Each dilution was replicated four times. From pea size, $50 \mathrm{~g}$ of berries instead of five bunches were picked at random per block.

Twenty leaves were picked at random in each block and cut into $\pm 1 \mathrm{~cm}^{2}$ pieces. Fifty grams of this material was shaken in a $1 \mathrm{~L}$ Erlenmeyer flask for $2 \mathrm{~min}$. in $200 \mathrm{ml}$ sterile distilled water, to which a drop of Tween 80 was added. Dilutions of the washings were then plated as described previously.

After incubation for $24 \mathrm{hr}$ at $24^{\circ} \mathrm{C}$ all NA dilution plates were sprayed with a $B$. cinerea spore suspension $\left(10^{4}\right.$ spores/ml). Dilution plates were incubated for a further $72 \mathrm{hr}$ at $24^{\circ} \mathrm{C}$, whereafter total bacterial counts, including colonies showing inhibition to $B$. cinerea and those not showing inhibition, were made. Bacterial colonies showing inhibition to $B$. cinerea were subsequently isolated onto Potato Dextrose

Acknowledgements: The author wishes to thank Ms H.A. Keyser for technical assistance, Mr D. Capatos for statistical analysis, and $\mathrm{Mr}$ A. van Rooyen for computing services. 
Agar (PDA) and purified for in vitro tests.

In vitro inhibition tests on PDA: Bacterial isolates were tested individually on PDA for the degree of inhibition to $B$. cinerea mycelium growth. Each isolate with an inhibitory potential was streaked onto the PDA in a petri dish and a disc (6 $\mathrm{mm}$ diameter) from a PDA culture of $B$. cinerea placed 40 $\mathrm{mm}$ from the bacteria. Three replicates were used for each bacterial isolate. After incubation for 5 days at $24^{\circ} \mathrm{C}$, inhibition zones were measured. The size of the inhibition zone indicated the relative activity of the specific bacterial isolate. Isolates showing inhibition zones exceeding $14 \mathrm{~mm}$ were used for further in vitro tests on grape berries.

In vitro inhibition on grape berries: Bacterial isolates were cultured in $200 \mathrm{ml}$ liquid medium (Czapek Dox) in $1 \mathrm{~L}$ Erlenmeyer flasks for 5 days at $24^{\circ} \mathrm{C}$ on a rotary shaker. Thereafter bacteria were centrifuged at $4000 \mathrm{rpm}$ for 20 minutes and the pellet of bacterial cells resuspended in 200 $\mathrm{ml}$ distilled water. The concentration of bacterial cells of each isolate was about $1 \times 10^{8}$ colony-forming units per $\mathrm{ml}$ as determined by dilution plate count. Trichoderma harzianum isolated from vine wood was also evaluated.

Ripe berries of the cultivar Waltham Cross were randomly selected from eight bunches and removed with their pedicels intact. Eight berries were dipped into each bacterial suspension. Berries dipped in sterile distilled water served as controls. These were placed in separate rows (40 $\mathrm{mm}$ apart) on expanded metal sheets in clear plastic-covered cages $(500 \mathrm{x}$ $400 \times 300 \mathrm{~mm}$ ). Each cage contained a stainless steel tray at the bottom in which a thin layer of water was poured to maintain a high relative humidity. After four hours' incubation at $24^{\circ} \mathrm{C}, 10 \mathrm{~m} /$ of a $10^{5} \mathrm{~B}$. cinerea spore suspension was sprayed onto the berries using a chromatographic sprayer. After further incubation for 10 days at $24^{\circ} \mathrm{C}$ the number of infected berries per treatment was determined. The experiment was repeated three times.

Treatments were compared with respect to the proportion of berries free from infection, using a one-way analysis of variance with a logit transformation, and Fisher's protected LSD test.
The evaluation of chemicals: A fluctuation in the total numbers of bacteria isolated from flowering till ripening led to the conclusion that the chemicals which had been used in a spray programme could be responsible.

Consequently, the effect of all the chemicals used were tested in vitro against sixteen of the bacterial isolates that showed the greatest inhibition to $B$. cinerea. Chemicals used were: folpet, mancozeb, bromopropylate, pyrifenox, copper oxychloride, magnesium sulphate, iprodione, procymidone and penconazole. Sterile filter-paper discs were dipped into the specific chemical at the concentration used commercially and placed onto PDA in petri dishes in which $1 \mathrm{ml}$ of a suspension of a specific bacterial isolate was added. After 48 hours' incubation at $27^{\circ} \mathrm{C}$, petri dishes were examined for inhibition of the bacteria by measuring the clear zone around the filter paper discs. The test was repeated three times for each of the bacteriai isolates.

\section{RESULTS AND DISCUSSION}

Eighty bacterial isolates which showed inhibition to germination of Botrytis spores were obtained. Thirty-six were isolated from bunches while the rest were obtained from leaves.

Inhibition on PDA: Only 16 of the 80 isolates showed inhibition zones $14 \mathrm{~mm}$ and larger after 5 days on PDA (Table 1). The largest inhibition zones were obtained with three isolates, one from bunches (K2) and two from leaves (PS3 and OG 18). The formation of an inhibition zone by the different isolates suggests the diffusion of an antifungal substance from the bacterial isolates through the PDA. Antibiotic production seems to be the major mode of action of most antagonists identified so far (Wilson \& Wisniewski, 1989).

In vitro inhibition on grape berries: Isolate $\mathrm{OB} 15 \mathrm{com}$ pletely controlled Botrytis on Waltham Cross berries over a 10-day incubation period at $24^{\circ} \mathrm{C}$ (Table 1 and Fig. 1). Janisiewicz $(1987,1988)$ and Chalutz \& Wilson (1989) isolated naturally occurring antagonists from the surface of apple and citrus respectively, which were effective biocontrol agents when reapplied to the fruit. Twelve isolates and $T$. harzianum (group B Table 1) were acceptably effective

\section{TABLE 1}

The effectiveness of several bacterial isolates, including Trichoderma harzianum against Botrytis cinerea on grape berries and potato-dextrose agar.

\begin{tabular}{|c|c|c|c|}
\hline Class $^{\mathrm{a}}$ & Isolate & $\begin{array}{c}\text { Effectiveness } \\
\text { (\% berries uninfected })\end{array}$ & $\begin{array}{c}\text { Inhibition zone on PDA } \\
\text { (mm) })\end{array}$ \\
\hline A & OB15 & 100 & 17 \\
B & $\begin{array}{c}\text { K2, K3, PB29, OB41, PG43, PS3, } \\
\text { K14, OB22, K5, PB24, PB28, } \\
\text { OG18, T. harzianum }\end{array}$ & $70,8-87,5$ & $15-16$ \\
C & Ot 57, K1 & $54,2-62,5$ & 16 \\
D & K8 & 41,7 & - \\
E & Control & 29,2 & - \\
\hline
\end{tabular}

${ }^{\text {a. }}$ Classification of isolates according to Fisher's protected LSD test.

Isolates in the same class do not differ at the $5 \%$ level of significance. 


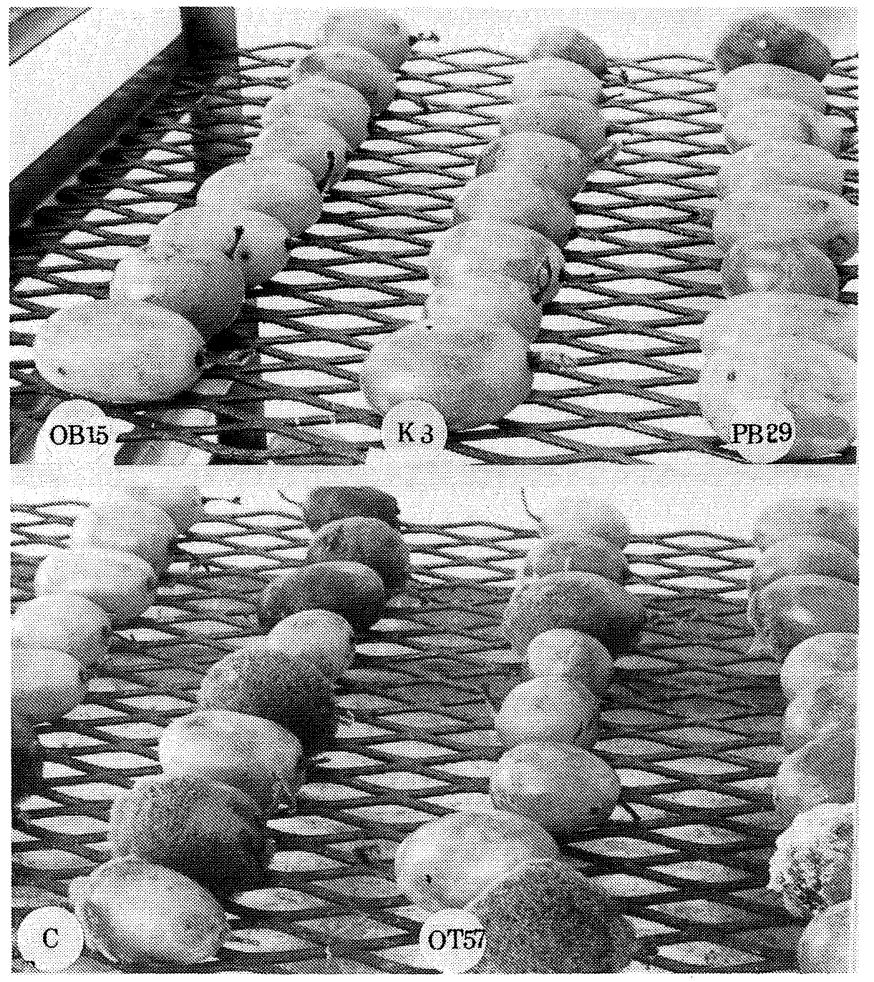

FIGURE 1

Botrytis development on Waltham Cross berries in vitro after treatment with bacterial isolates OB15, K3, PB29, OT57 and untreated C.
(70\%) under conditions extremely favourable for the pathogen.

No apparent correlation exists between inhibition on grape berries and PDA. For example, isolate OB15 showed a moderate inhibition zone $(17 \mathrm{~mm})$ on PDA (Table 1$)$, but completely controlled $B$. cinerea on berries. Some of the bacterial isolates restricted infection to pedicels (K3) and (PB29) (Fig. 1). Untreated control berries were infected to a very high degree. Three isolates viz. PS3, K2 and OG18, gave inhibition zones of $20 \mathrm{~mm}$ on PDA but were less effective on berries. This was not surprising, however, because similar discrepancies have been reported (Cook \& Baker, 1983). Once infected, most of the berries were completely colonized by $B$. cinerea.

The evaluation of chemicals: Mancozeb, folpet and iprodione caused inhibition of the 16 bacterial isolates used. Mancozeb was the most bactericidal with an inhibition zone of $9 \mathrm{~mm}$, copper oxychloride $3,3 \mathrm{~mm}$, folpet $1,8 \mathrm{~mm}$ and iprodione $1,7 \mathrm{~mm}$.

The strong bactericidal effect of mancozeb, and to a lesser extent copper oxychloride, could be the reason for the initial low numbers of bacteria isolated (Fig. 1). The sudden drop in bacterial numbers recorded on the third of January could again be due to mancozeb application on the 22nd of December.

\section{CONCLUSIONS}

Epiphytic bacteria with inhibitory effects on the spore germination and mycelium growth of $B$. cinerea occur

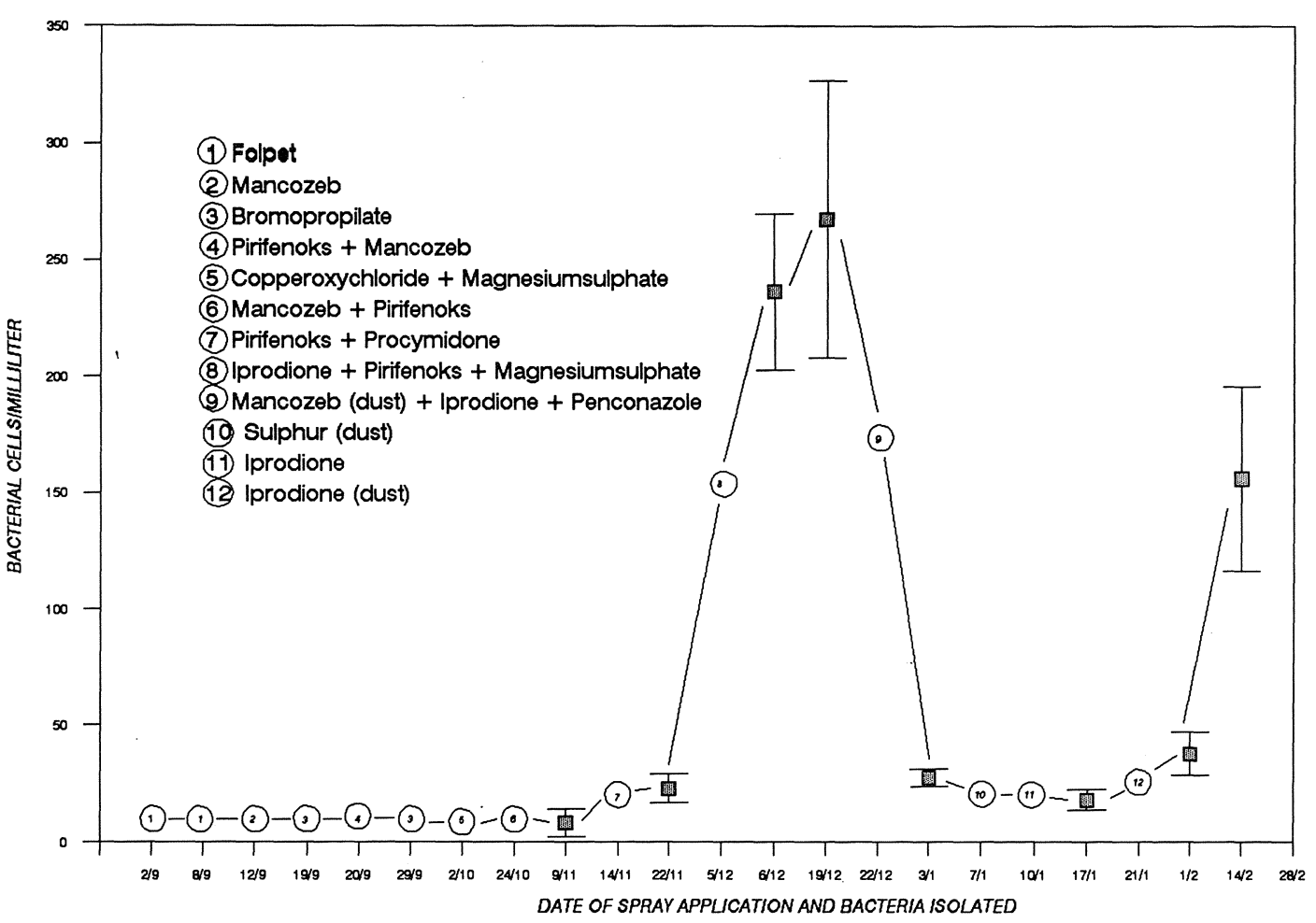

FIGURE 2

Epiphytic bacteria isolated with two-weekly intervals from Waltham Cross leaves starting at full bloom. Encircled numbers indicate the type of fungicide applied, whereas squares indicate the date of bacterial isolation. Vertical cross bars indicate standard error. 
naturally on both leaves and bunches of Waltham Cross grapevines. The inhibitory effects of these bacteria are assumed to be caused by antibiotic production. A number of these bacterial isolates gave good in vitro control of $B$. cinerea on Waltham Cross berries. Although the biological control of $B$. cinerea by means of antagonistic bacterial isolates seems possible, the effectiveness of these isolates will have to be determined in vivo. All but one of the isolates used were tentatively identified as Bacillus spp.

Mancozeb, which is being applied for the control of downy mildew, can cause a pronounced decrease in the epiphytic bacterial population on leaves and bunches. This fungicide will have to be excluded from future in vivo biological control trials.

\section{LITERATURE CITED}

BAKER, K.F. \& COOK, R.J., 1973. Biological control of plant pathogens. The American Phytopathological Society, 3340 Pilot Knob Road, St. Paul, Minnesota 55121, U.S.A

BLAKEMAN, J.P. \& BRODIE, I.O.S., 1977. Competition for nutrients between epiphytic microorganisms and germination of spores of plant pathogens on beetroot leaves-Physiol. Plant Pathol. 10, 29-42.

CHALUTZ, E. \& WILSON, C.L., 1989. Biocontrol of postharvest diseases of citrus by Debaromyces hansenii. Plant Dis. In press.

COOK, R.J. \& BAKER, K.F., 1983. Developmental history of biological control of plant pathogens. In: The nature and practice of biological control of plant pathogens. American Phytopathological Society, St. Paul, MN, pp. 30-54.

DENNIS, C. \& DAVIS, R.P., 1979. Tolerance of Botrytis cinerea to iprodione and vinclozolin. Plant Pathol. 28, 131-133.

DENNIS, C. \& WEBSTER, J., 1971a. Antagonistic properties of specie-groups of Trichoderma. I. Production of non-volatile antibiotics. Trans. Br. Mycol. Soc. 57, 25-39.

DENNIS, C. \& WEBSTER, J., 1971b. Antagonistic properties of specie-groups of
Trichoderma. II. Production of volatile antibiotics. Trans. Br. Mycol. Soc. 57, 41-48.

DUBOS, B., 1984. Biocontrol of Botrytis on grapevines by an antagonistic strain of Trichoderma harzianum. In: Klug, M.J. and Reddy, G.A. (eds.) Current perspectives in Microbiol Ecology, eds. Elsevier Science Publishers B.V. Amsterdam. pp. 370-373.

FRAVEL, D.R. \& SPURR, H.W., 1977. Biocontrol of tobacco brown-spot disease by Bacillus cereus subsp. mycoides in a controlled environment. Phytopathology 67, 930-932.

JANISIEWICZ, W.J., 1987. Postharvest biological control of blue mold on apple. Phytopathology 77, 481-485.

JANISIWIECZ, W.J., 1988. Biocontrol of postharvest diseases of apples with antagonist mixtures Phytopathology 78, 194-198.

KATAN, T., 1982. Resistance to 3,5-dichlorophenyl -N-cycle imide ("dicarboximide") fungicides in the grey mould pathogen Botrytis cinerea on protected crops, Plant Pathol. 31, 133-141.

LEBEN, C., 1965. Epiphytic microorganisms in relation to plant disease. Annu. Rev. Phytopathol.3, 209-250.

LE ROUX, P., GREDT, M. \& FRITZ, R., 1981. Resistance to 3,5-dichlorophenyl -N-cyclic-imide fungicides. Neth. J. Plant Pathol. 87, 244-245.

NELSON, M.E. \& POWELSON, M.L., 1988. Biological control of grey mold on snap beans by Trichoderma hamatum. Plant Dis. 72, 727-729.

REDMOND, J.C., MAROIS, J.J. \& MACDONALD, J.D., 1987. Biological control of Botrytis cinerea on roses with epiphytic microorganisms. Plant Dis. 71, 799-802.

THOMAS, A.C., 1983. Epidemiology of Botrytis rot of table grapes in South Africa. D.Sc (Agric.) thesis University of Pretoria, 0001 Pretoria, Republic of SA. pp. 137.

TRONSMO, A. \& DENNIS, C., 1977. The use of Trichoderma species to control strawberry fruit rots. Neth. J. Plant. Pathol.-83, 449-455.

UTKHEDE, R.S. \& SHOLBERG, P.L., 1986. In vitro inhibition of plant pathogens by Bacillus subtilis and Enterobacter-aerogenes and in vivo control of two post harvest cherry diseases, Can. J. Microbiol. 32, 963-967.

WOOD, R.K.S., 1950. The control of diseases of lettuce by the use of antagonistic organisms. I. The Control of Botrytis cinerea Pers. Ann. Appl. Biol. 38, 203-216.

WILSON, C.L. \& Wisniewski, M.E., 1989. Biological control of post harvest diseases of fruits and vegetables: An emerging technology. Annu. Rev. Phytopathol. 27, 425-441. 